\title{
Whole Language-Based English Reading Materials
}

\author{
Dian Erlina (Corresponding author) \\ Universitas Islam Negeri Raden Fatah, Palembang, Indonesia \\ E-mail: dianerlina02@gmail.com \\ Ilza Mayuni \\ Universitas Negeri Jakarta, Indonesia \\ Sabarti Akhadiah \\ Universitas Negeri Jakarta, Indonesia
}

Received: 17-11-2015

Published: 01-05-2016
Accepted: $30-01-2016$

doi:10.7575/aiac.ijalel.v.5n.3p.46
Advance Access Published: March 2016

URL: http://dx.doi.org/10.7575/aiac.ijalel.v.5n.3p.46

\begin{abstract}
This Research and Development (R\&D) aims at developing English reading materials for undergraduate EFL students of Universitas Islam Negeri (UIN) Raden Fatah Palembang, Indonesia. Research data were obtained through questionnaires, tests, and documents. The results of the research show that the existing materials are not relevant to the students' need, so there is a need for developing new materials based on whole language principles. In general, the new developed materials are considered reliable by the experts, students, and lecturers. The materials are also effective in improving students' reading achievement. The final product of the materials consists of a course book entitled Whole Language Reading (WLR) and a teacher's manual. WLR provides rich input of reading strategies, variety of topics, concepts, texts, activities, tasks, and evaluations. Using this book makes reading more holistic and meaningful as it provides integration across language skills and subject areas.
\end{abstract}

Keywords: materials development, reading materials, whole language

\section{Introduction}

Reading is an important part of a person's English language proficiency. In the academic context, reading is considered one of the most important skills that English as a Foreign Language (EFL) students need to acquire because the ability to read English texts greatly affects students' academic performance, particularly in cases where they have to read for their own specialist subject (McDonough \& Shaw, 2005, p. 5; Sidek, 2012, p. 109; Bastug, 2014, p. 931). But, reading is a complex process (Harwood, 2010, p. 132; Hedgcock \& Ferris, 2009, pp. 2-3). Readers must be able to use a variety of reading strategies appropriately, access the meaning of vocabulary accurately, access their knowledge of English grammar, and draw upon their background knowledge and relate it to the materials they are reading. Therefore, reading instructors face the challenge of teaching the students the skills needed to be successful readers. Especially, they need to develop appropriate materials for teaching reading because instructional materials serve as the basis of the language input and language practice for the students (Richards, 2005, p. 251). Materials contain the content that students will use to achieve learning objectives (Dick et al., 2009, p. 230). In addition, numbers of research publications in various countries show the power of instructional materials in facilitating students in language learning (Tomlinson \& Masuhara, 2010, p. 1).

Reading instruction has been the main concern of English teaching program for undergraduate EFL students at UIN Raden Fatah Palembang, Indonesia. However, most of the students have insufficient competence in reading English texts. This due to ineffective reading strategies use, lack of English vocabulary and grammar knowledge, and also lack of familiarity with the content of the texts. The concern of this study is related to the reading materials they are using. In fact, the students are not satisfied with the existing materials, since they do not fit well within their needs and interests. They are comprehension-based materials; texts are followed by a number of questions to test students' comprehension, but they do not provide students with explicit strategy training to be successful readers. Besides, they do not give opportunities for students to deal with varied of texts, topics, and activities. Therefore, this study aims at developing English reading materials that are relevant to the students' needs and explicitly teach the strategies to read various texts in English. To meet this aim, the following research questions are asked in this study.

1. What are the students' needs related to their English reading materials?

2. What reading materials model is appropriate to be developed?

\section{Theoretical Review}

Research and development is a type of research that is done to bridge the gap that often occurs between educational research and educational practice. Therefore, this type of research is often used to solve practical problems in education. For example, it is used to develop and validate educational products and procedures, which are systematically field- 
tested, evaluated, and refined until they meet specified criteria of effectiveness or quality standard (Gall et al., 2007, p. 589). The steps of this process are usually called the R\&D cycle, which consists of studying research findings related to the product to be developed, developing the product, field testing and revising the product until the product meets its defined objectives (Borg \& Gall, 1983, pp. 772-775).

According to Masuhara (as cited in Tomlinson, 2007, pp. 341-349), there are several models of second/foreign language reading instruction that can be used as the basis for developing English reading materials. Some of them are (1) reading comprehension-based approach, (2) language-based approach, (3) (skills/strategies-based approach), and (4) schemabased approach. Reading comprehension-based materials emphasize students' comprehension of the texts. In this model, texts are followed by reading comprehension questions presented in the form of exercises or tasks to develop reading skills. Language-based reading materials emphasize the aspects of grammar and lexis. Therefore, learning activities begin with the elements of vocabulary and grammar of text, so the students can read fluently. Skills/strategiesbased reading materials emphasize the aspects of reading skills/strategies. The materials include learning about set of skills/strategies for developing reading skills. Schema-based reading materials give emphasis on the importance of knowledge/experience gained from the texts compared to similar knowledge/experience in students' memory. Therefore, learning begins with the presentation of several activities to activate students' background knowledge/experience related to the text.

In addition to those models above, whole language-based instruction can also be applied in developing reading materials. Whole language approach has been considered in language teaching program in western countries since 1980s. Weaver (1990, p. 3) and Taylor (2007, p. 3) emphasize that whole language is a teaching philosophy. Kenneth Goodman (2005, p. 1) states that whole language is a way of bringing together the views of language, learning, students and teachers as the basis for the practice of language learning. Whole language regards language as a whole. The wholeness of language implies that language is not the sum of its many dissectible and discrete parts (Brown, 2007, p. 54). Language is taught in an integrated and interdisciplinary learning. not fragmented into skills, in authentic literacy events, reading and writing experiences permeate the whole curriculum, and learning within the classroom is integrated with the real life of the students (Weaver, 1990, p. 6). In other words, integration in whole language concept refers to integration of the language arts as well as integration of the language arts across the curriculum (Routman, 1991, p. 276). Integration of learning across subject areas can be done naturally by using a thematic unit. A thematic unit is a method of organizing instructional time and materials around a topic for integrating contents (Eisele, 1991, p. 53). The relationships among the disciplines or subject areas must be meaningful and natural. Concepts identified are not only related to the topic but are important for the students (Routman, 1991, p. 277).

Several studies have shown the effectiveness of the application of whole language principles in teaching English as a foreign language at primary, secondary, and higher education (Wang, 2011, p. 11). Moghadam states that the implementation of an integrated learning can help students develop communicative competence and increase awareness for the study (2011, p. 1652). Qiang et al., also proves that the best way to improve students' foreign language acquisition is through reading, listening, writing, and speaking English holistically (2008, p. 45). Moreover, Alhaddad reports that the application of the whole language principles in teaching reading can increase students' independence in learning, improve students' higher order thinking skills and ability to work collaboratively (2014, p. 418).

Generally, those studies indicate that students get more benefits from whole language-based learning. Whole language keeps language whole and real. Students learn better and easier when surrounded by real language. Integrating language skills and content in language program puts language into a larger and more meaningful context. Integrated reading instruction is also applicable for university education courses. Through integrated instruction, students become cognitively engaged in language and content and also actively involved in rich and meaningful learning activities. For example, the students involve in reading the text, discussing the content, note-taking and discussing the usage of words and grammatical items in the text, summary writing and presenting it in class discussion, etc. With the blend of language skills and content in reading program, language takes its rightful function as a tool for communication and expression of thought. As the students' knowledge of content grows, their vocabulary and linguistic forms also grow with it. Therefore, this study aims at developing integrated English reading materials to enrich learning and make reading more meaningful and useful for the students.

Figure 1 below shows the integration of learning in English reading materials based on the concept of whole language.

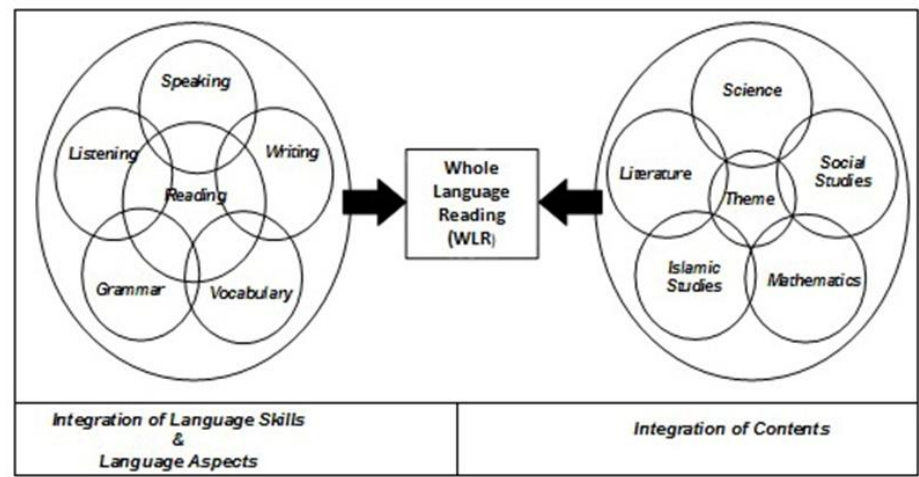

Figure 1. Integration of Learning in Whole Language-Based English Reading Materials 
The integration occurs through the implementation of several strategies of teaching reading and use of English in some subject areas (Science, Social Studies, Mathematics, Islamic Studies, and Literature).

\section{Methodology}

\subsection{Participants}

100 students from four different Reading IV classes of English Education Study Program at UIN Raden Fatah Palembang and 3 reading instructors participated in filling out the questionnaire for need analysis of English reading materials. 15 students and 3 reading instructors participated in small group field testing of new developed materials. 32 students and 2 reading instructors participated in large group field testing. 68 students (34 in control group and 34 in treatment group) and 1 reading instructor participated in the experiment to test the effectiveness of the new developed materials in improving students' reading achievement. They were second-year learners and instructed by an English lecturer who had at least 3 years of experience in teaching reading. All the participants were native Indonesian-speaking learners.

\subsection{Data Collection}

Related to the needs analysis of reading materials and reliability of existing reading materials used in Reading IV classes, three sets of questionnaire were administered. The first was consisting of 100 questions related to necessities and wants; what must be learned in reading IV class and what do the learners wish to learn?. The second was consisting of 30 questions related to lacks; what do the learners lack? The third was consisting of 36 questions related to evaluation of existing reading materials. These three sets of questionnaire were completed by 100 students and 3 reading instructor. In relation to students' and instructors' perceptions toward new developed reading materials, a set of questionnaire of 50 questions was completed by 32 students and 2 reading instructors who were willing to implement the new developed materials in their Reading IV classes for large group field testing. The questionnaires were measured on a five-point Likert type scale. Then, expert judgments toward the new developed materials were done by 2 experts who had the qualification and experience in materials development. Tests (pretest and posttest) of 50 reading comprehension questions were administered to obtain data on students' reading achievement after the treatment and cloze test of 80 questions was given to 32 students who participated in large group field testing to figure out the readability level of the texts. Documents review was also used in analyzing the syllabus and the existing English reading materials that currently used in Reading IV classes.

\subsection{Procedures}

Product development in this study was conducted through the implementation of educational research and development stages or the procedural model (R\&D cycle) by Borg \& Gall (1983, pp. 772-775) and the framework for teaching materials writing by Jolly \& Bolitho (2011, pp. 112-113). The stages in developing the product are as follows:

First, preliminary study (January-May 2013), which consists of (1) conducting a literature review, (2) reviewing the English reading materials that are currently used, (3) conducting need analysis of English reading materials, and (4) developing preliminary form of product.

Second, development of the product (June-November 2013), which includes (1) determining learning objectives, (2) determining the themes, (3) collecting texts, (4) selecting texts, (5) organizing texts, (6) developing learning activities, (7) developing tasks and evaluation, (8) illustrations and typographical arrangement, and (9) developing draft of syllabus and teaching materials.

Third, validation, evaluation, and revision of the product (December 2013-January 2015), which consists of (1) experts judgments of the product, (2) the first phase revision of the product as suggested by the experts, (3) field testing of the product to small group, (4) the second phase revision of the product as suggested by small group-test results, and (5) field testing of the product to large group through experimental design using one-shot case study, (6) the third phase revision of the product as suggested by large group-test results, (7) readability test, through readability formulas (Flesch Readability East) and reader response (cloze test), (8) users' perceptions test through a set of questionnaire distributed to students and instructors who participated in the large group field testing to determine their experience and perceptions toward the product, (9) final product revision, and (10) effectiveness testing of the product through experimental design using pretest-posttest control group design to assess the impact of using the product on students' reading achievement.

\subsection{Data Analysis}

Data from questionnaires were collected from the rating scales and the categorical items in simple tally and presented in the form of frequency tables to show the percentages of cases in each scale and category. All responses and comments to the open questions were reviewed and grouped into some meaningful categories as they provide useful information for revising the product.

To determine the readability level of the texts used in new developed reading materials, the following are the categories of readability level and reader grade level according to Flesch Readability East Formula and Flesch-Kincaid Grade Level.

Score

90-100 very easy

80-90 easy 
70-80 fairly easy

60-70 normal

50-60 fairly difficult

30-50 difficult

00-30 very difficult

Scores between 90.0 and 100.0, considered easily understandable by 5th grader. Scores between 60.0 and 70.0, considered easily understood by 8th \& 9th graders. Scores between 0.0 and 30.0 , considered easily understood by college graduates

Then, in effectiveness testing of the new developed reading materials, independent sample t-test was used to compare students' reading comprehension scores, both in control and experimental groups. A significant difference is found when the significant value is lower than .05 .

\section{Findings}

\subsection{Answer to the first research question}

The students required reading materials that provide explanation of (1) variety of reading strategies and guidelines in applying the strategies, tasks associated with the use of each of the strategies in a pre-reading activities, whilst reading activities, and post reading activities, (2) various types and genres of texts such as informative, exposition, procedural, descriptive, argumentative, narrative, and persuasive texts, and various genres of texts, particularly academic essays, newspapers, magazines, short stories, biographies, poems, and play scripts. (3) various text topics, which are important and closer to their daily lives, especially the topics of environment, water, human body, health, electricity, pollution, plants, garbage, air, soil, disaster or natural phenomena, (4) learning activities, which are closely related to their difficulties in reading English texts. Activities include a variety of exercises needed to perform scanning, skimming, drawing conclusions, developing vocabulary related to the text, presenting what is learned from a text, synthesizing information from a text, summarizing information from a text, predicting a text, applying information learned from a text, develop grammatical knowledge related to the text, drawing conclusions from the images or illustrations in the text, guessing the meaning of words or phrases based on the context, finding topics, main idea and supporting ideas, previewing text, paraphrasing a sentence or paragraph in the text, identifying the author's purpose, making connections in reading a text, criticizing author's opinion in a text, using a graphic organizer to represent the relationship among key ideas in a text, identifying author's viewpoints, generating questions about the text, identifying text structure and discourse markers in a text.

\subsection{Answer to the second research question}

Based on the results of need analysis, whole language-based English reading materials are appropriate to develop. Language is kept whole, not fragmented into skill, so these materials integrate reading, writing, listening, speaking, vocabulary, and grammar learning in its learning activities. English is taught by using content from other disciplines. Each unit of this book provides a number of authentic texts related to Science, Social Studies, Mathematics, Islamic Studies, and Literature with a central theme and concept.

Whole language-based English reading materials developed in this study has several characteristics as follows. First, integrated learning, it means that the teaching of reading give emphasis on the meaningful whole language activities including listening, speaking, writing activities, and consideration to the study of vocabulary and grammatical items, and the content of the texts in multiple subject areas. Second, thematic, it means that the organization of materials and learning activities in each learning unit is based on a series of English text associated with a theme or concept to be developed. Third, authentic, English texts used are the original texts or written for the actual purposes, not intentionally written for the sake of teaching the language, vocabulary and linguistic structures are not simplified to introduce the reality of actual language usage. Fourth, contextual, it means that reading instruction emphasizes students' comprehension toward texts in a comprehensive manner by associating the information in the text in students' real-life experience. Based on the principle of whole language, language learning becomes easier when it is real, relevant, and be in the context of its use. Fifth, collaborative, the learning process always involves students in activities to share, discuss, and cooperate in building their knowledge and skills. Collaborative learning can help students of all levels of reading ability to enjoy reading.

The results of expert judgments showed that the new developed materials were considered reliable by the experts (mean score 3.46) in terms of the ten aspects of assessment, namely (1) the purpose and concept, (2) texts presented, (3) information presented, (4) materials organization, (5) exercises presented, (6) evaluation, (7) language use, (8) typographical arrangement, (9) illustration, and (10) supplemental materials. However, there were some items required some revisions such as clarity of information about source of texts, image/photo used in the texts, and availability of tests and other evaluation types. Comments and suggestions given by the experts were also considered in revising the materials.

The readability test results showed that the average Flesch Readability East score was 57.2. This score indicates that the readability of the texts was at a level of fairly difficult. Referring to the Flesch-Kincaid Grade Level, those texts were suitable for college-level readers (Bravos, 2010). In addition, the results of the cloze test showed that the students' mean 
score was 64.07. This score showed that the texts were at instructional level or suitable for instructional purpose (good for learning at instructional level) (Nation, 2009, p. 84).

The students' and instructors' perceptions toward new developed reading materials were good. The mean score of students' perception was 3.83 and the mean score of instructors' perception was 3.79. However, there were some suggestions or inputs given by the instructors and students for revising the materials. After a series of research and development process, starting from the preliminary stage, development stage, as well as validation, evaluation, and revision of the product, whole language-based English reading materials were considered final and can be used in. The physical structure of reading materials entitled Whole Language Reading (WLR) was illustrated in Figure 2.

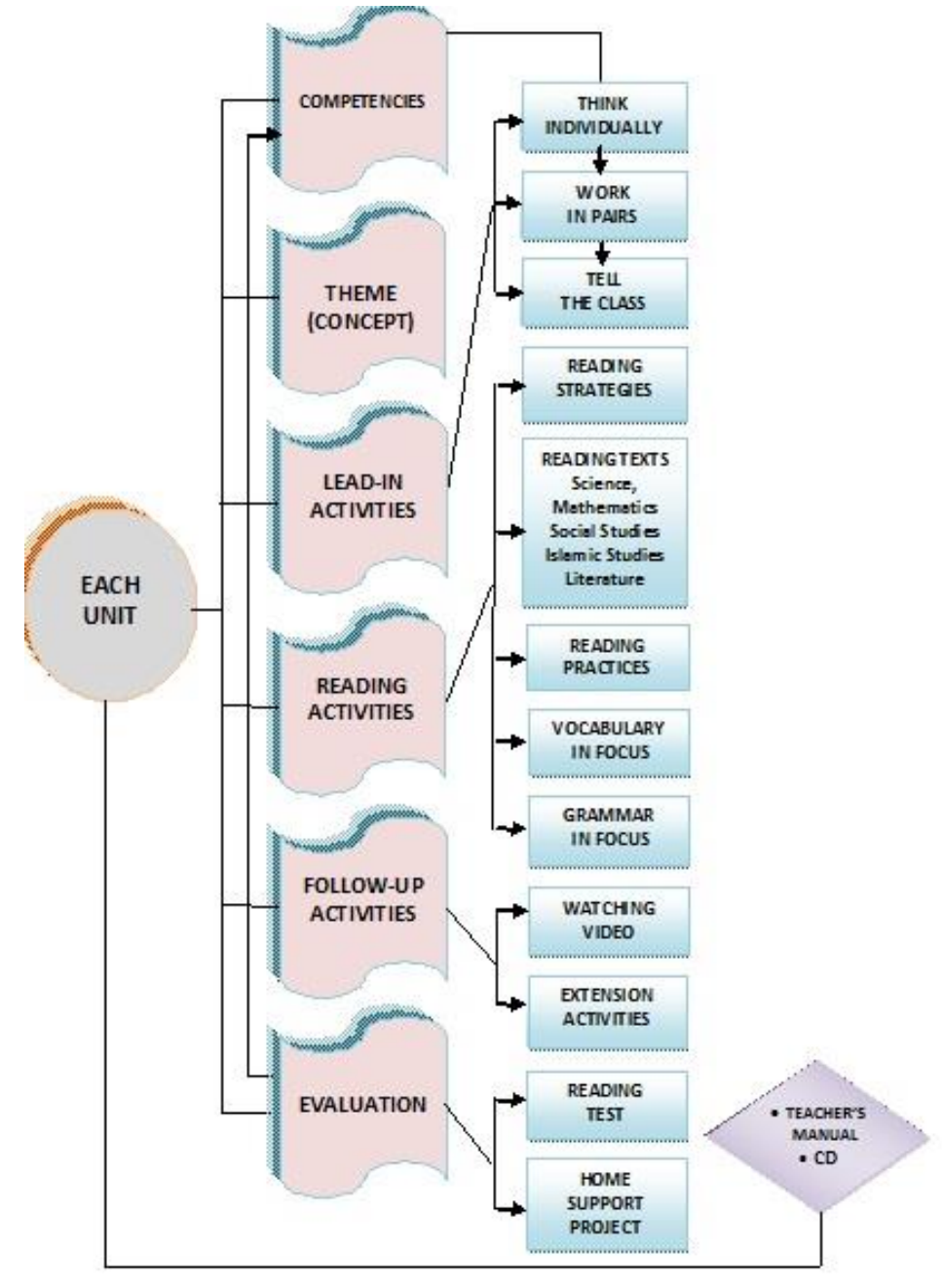

Figure 2. The Structure of Whole Language-Based English Reading Materials

Whole Language Reading (WLR) consists of seven units. Each unit has a central theme, five reading texts, and numbers of activities, tasks, and evaluations. Activities are divided into three parts; lead-in activities, reading activities, and follow up-activities. Lead-in activities start with some pictures, followed by pre-reading questions to introduce the topic, generate interest, and activate students' schema. Reading activities begin with the explanation of reading strategies, followed by explanation of vocabulary and grammatical items, and some practices to develop students' reading skills. Follow-up activities consist of some reinforcement activities about the concept developed in each unit. This book is accompanied by a teacher's manual to guide the teacher in using it. Evaluations consist of reading test and home support project. The contents of Whole Language Reading (WLR) can be seen in Table 1 below.

Table 1. The Contents of Whole Language-Based English Reading Materials

\begin{tabular}{|c|c|c|c|c|}
\hline \multicolumn{5}{|c|}{ CONTENTS } \\
\hline Concepts & Objectives & Skills \& Materials & $\begin{array}{l}\text { Linguistic } \\
\text { Features }\end{array}$ & Pages \\
\hline \multicolumn{5}{|c|}{ Unit 1 - WATER } \\
\hline $\begin{array}{l}\text { Save Water } \\
\text { Can Save } \\
\text { Life }\end{array}$ & $\begin{array}{l}\text { The students are } \\
\text { able to: } \\
\text { - Preview a text } \\
\text { - Identify } \\
\text { keywords }\end{array}$ & $\begin{array}{l}\text { READING: } \\
\text { Reading the following texts: } \\
\text { - Science } \\
\text { The Science of Water: Nature's } \\
\text { Most Important Nutrient }\end{array}$ & $\begin{array}{l}\text { VOCABULARY } \\
\text { Measurement } \\
\text { Unit Words } \\
\text { GRAMMAR } \\
\text { Modal Verbs }\end{array}$ & $1-32$ \\
\hline
\end{tabular}


- Make predictions about a text

- Generate questions about a text
- Mathematics

How to Calculate How Much

Water to Drink Daily?

- Social Studies

Water Scarcity in Africa

- Islamic Studies

How Islam Could Help Fight

Water Scarcity

- Literature

How to Read a Poem?

Poems "Save Water Save Life"

LISTENING:

Listening to the speakers in the video "A Pleasant and Water Efficient Day", partner's response, other students' comments

SPEAKING:

Telling, discussing, presenting ideas, asking/answering questions, asking/giving comments, reciting surah, presenting poems

WRITING:

Writing answers, main points, conclusions, paragraphs, and reading reports

\begin{tabular}{|c|c|c|c|c|}
\hline \multicolumn{5}{|c|}{ Unit 2 - TREES } \\
\hline \multirow{5}{*}{$\begin{array}{l}\text { Save Trees } \\
\text { Because } \\
\text { They Give } \\
\text { Us Many } \\
\text { Benefits }\end{array}$} & \multirow{27}{*}{$\begin{array}{l}\text { The students are } \\
\text { able to: } \\
\text { - Skim a text } \\
\text { using } \\
\text { introductory } \\
\text { and } \\
\text { concluding } \\
\text { paragraphs } \\
\text { - Skim a text } \\
\text { using section } \\
\text { headings } \\
\text { - Skim a text } \\
\text { using the first } \\
\text { line of each } \\
\text { paragraph }\end{array}$} & READING: & VOCABULARY & \multirow[t]{27}{*}{$33-61$} \\
\hline & & Reading the following texts: & Multiple & \\
\hline & & - Science & Meaning Words & \\
\hline & & Trees \& Their Benefits & & \\
\hline & & - Social Studies & GRAMMAR & \\
\hline & & Social Function of Trees & Phrasal Verbs & \\
\hline & & - Mathematics & & \\
\hline & & How Many Trees Are Really & & \\
\hline & & Saved through Paperless & & \\
\hline & & Statement? & & \\
\hline & & - Islamic Studies & & \\
\hline & & Going Green: Not New in Islam & & \\
\hline & & - Literature & & \\
\hline & & Folklore: & & \\
\hline & & Tree of Life: The Coconut Palm & & \\
\hline & & LISTENING: & & \\
\hline & & Listening to the speakers in the & & \\
\hline & & video "Save as WWF, Save a Tree" & & \\
\hline & & \& "Wedding Couples Plant Trees in & & \\
\hline & & West Java, Indonesia”, partner's & & \\
\hline & & response, students' comments & & \\
\hline & & SPEAKING: & & \\
\hline & & Telling, discussing, presenting ideas, & & \\
\hline & & asking and answering questions, & & \\
\hline & & asking/giving comments & & \\
\hline & & WRITING: & & \\
\hline & & $\begin{array}{l}\text { Writing answers, main points, } \\
\text { conclusions, short essays, and } \\
\text { reading reports }\end{array}$ & & \\
\hline \multicolumn{5}{|c|}{ Unit 3 - ELECTRICITY } \\
\hline \multirow{8}{*}{$\begin{array}{l}\text { Save } \\
\text { Electricity } \\
\text { Can Save } \\
\text { Energy }\end{array}$} & \multirow{8}{*}{$\begin{array}{l}\text { The students are } \\
\text { able to: } \\
\text { - Scan a text for } \\
\text { specific } \\
\text { information } \\
\text { - Scan a table } \\
\text { for specific } \\
\text { information }\end{array}$} & READING: & VOCABULARY & \multirow[t]{8}{*}{$62-87$} \\
\hline & & Reading the following texts: & Synonyms \& & \\
\hline & & - Science & Antonyms & \\
\hline & & What Is Electricity? & & \\
\hline & & - Islamic Studies & GRAMMAR & \\
\hline & & Islamic Prophecies: Electric Light & Relative Clauses & \\
\hline & & Bulbs & & \\
\hline & & - Social Studies & & \\
\hline
\end{tabular}


- Make

Benjamin Franklin, the Father of

connections in

Electricity

reading a text

- Mathematics

How Much Electricity Am I

Using?

- Literature

Short Stories "A Day without

Electricity"

LISTENING:

Listening to the speakers in the video "Top 10 Ways to Save

Electricity at Home", partner's

response, other students' comments

SPEAKING:

Telling, discussing, presenting ideas, asking/answering questions, and asking/giving comments

\section{WRITING:}

Writing answers, main points, conclusions, and reading reports

$\begin{array}{ll}\text { Reduce, } & \text { The students are } \\ \text { Reuse, \& } & \text { able to: } \\ \text { Recycle: } & \bullet \text { Identify text } \\ \text { Alternatives } & \text { structures } \\ \text { for Waste } & \bullet \text { Identify signal } \\ \text { Manage- } & \text { words } \\ \text { ment } & \text { • Use graphic } \\ & \text { organizer to } \\ & \text { represent the } \\ & \text { relationship } \\ & \text { among key } \\ & \text { ideas } \\ & \text { - Make } \\ & \text { inference } \\ & \text { from } \\ & \text { a play script }\end{array}$

\section{Unit 4 - SOLID WASTE}

READING

Reading the following texts:

- Mathematics

Garbage: Indonesia Produces 500

Million Liters Per Day

- Social Studies

What Are the Effect of Poor Waste

Management?

VOCABULARY

$88-118$

Verb Prefixes

with Specific

Meanings

\section{GRAMMAR}

Adjective Ending

in -ing and -ed

\section{- Science}

Three Rs - Reduce, Reuse,

Recycle

- Islamic Studies

Why Don't Muslim Families

Recycle?

- Literature

Play script "A Day in The Life of a

Waste Picker"

\section{LISTENING:}

Listening to the speakers in the video "What Can I Recycle?, partner's response, other students' comments

\section{SPEAKING :}

Telling, discussing, presenting ideas, asking and answering questions, asking/giving comments , and performing play script

"A Day in The Life of a Waste

Picker"

WRITING:

Writing answers, main points, conclusions, and reading reports

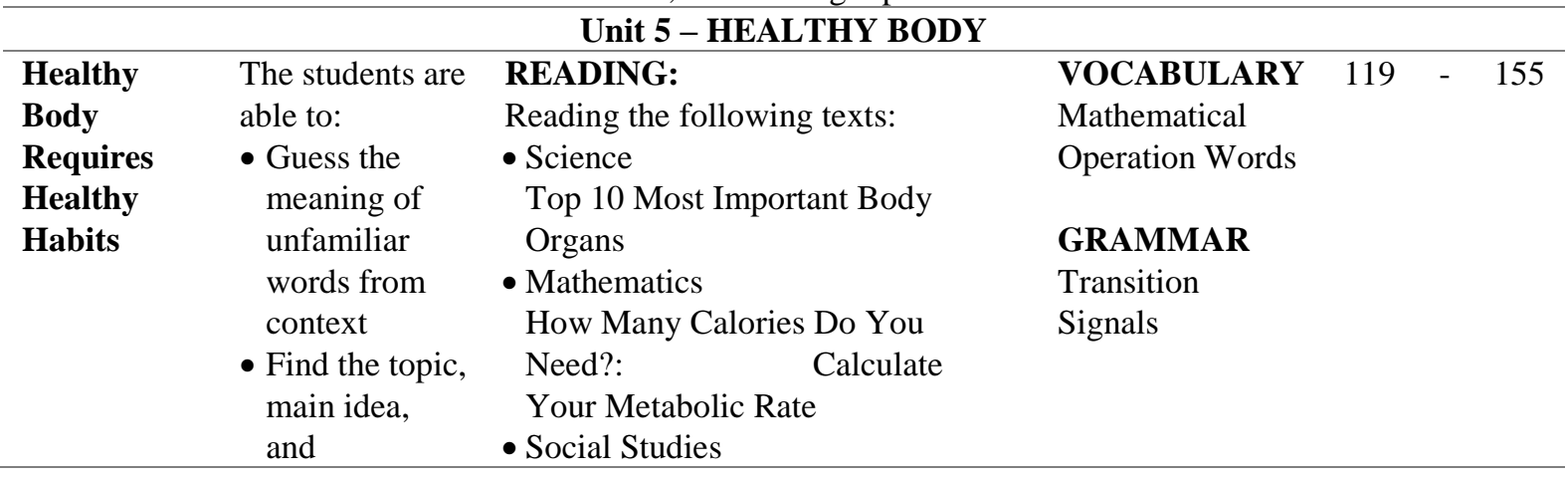




supporting
details of
a paragraph
Paraphrase
information in
a text
Map a story
using graphic
organizer

The Importance of Social

Interaction to Human Health

- Islamic Studies

Health Guidelines from Quran and

Sunnah

- Literature

Story "Health Vs Wealth"

\section{LISTENING:}

Listening to the speakers in the video "How to Live With a Healthy

Body and Mind", partner's response, other students' comments

\section{SPEAKING:}

Telling, discussing, presenting ideas, asking and answering questions, asking/giving comments

WRITING:

Writing answers, main points, conclusions, tips for healthy living, and reading reports

\begin{tabular}{|c|c|c|c|c|}
\hline \multicolumn{5}{|c|}{ Unit 6 - ENVIRONMENTAL POLLUTION } \\
\hline $\begin{array}{l}\text { Stop } \\
\text { Pollution to } \\
\text { Save Our } \\
\text { Environ- } \\
\text { ment }\end{array}$ & $\begin{array}{l}\text { The students are } \\
\text { able to: } \\
\text { - Make } \\
\text { inference } \\
\text { from a text, } \\
\text { picture, and } \\
\text { review } \\
\text { - Identify the } \\
\text { author's } \\
\text { viewpoint } \\
\text { - Identify the } \\
\text { author's } \\
\text { purpose }\end{array}$ & $\begin{array}{l}\text { READING: } \\
\text { Reading the following texts: } \\
\text { - Science } \\
7 \text { Kinds of Environmental } \\
\text { Pollution } \\
\text { - Social Studies } \\
\text { Most Polluted Cities in the World } \\
\text { - Literature } \\
\text { Book Review "A River Ran Wild" } \\
\text { - Mathematics } \\
\text { How Much Air Pollution Comes } \\
\text { from Car? } \\
\text { - Islamic Studies } \\
\text { How Islam Protects Environment } \\
\text { LISTENING: } \\
\text { Listening to the speakers in the } \\
\text { video "Pollution (Land, Air and } \\
\text { Water Pollution", partner's response, } \\
\text { other students' comments } \\
\text { SPEAKING: } \\
\text { Telling, discussing, presenting ideas, } \\
\text { asking and answering questions, } \\
\text { asking/giving comments } \\
\text { WRITING: } \\
\text { Writing answers, main points, } \\
\text { conclusions, and reading reports }\end{array}$ & $\begin{array}{l}\text { VOCABULARY } \\
\text { Noun Suffixes } \\
\text { GRAMMAR } \\
\text { Passive } \\
\text { Sentences }\end{array}$ & $156-186$ \\
\hline \multicolumn{5}{|c|}{ Unit 7 - NATURAL DISASTERS } \\
\hline $\begin{array}{l}\text { Gain More } \\
\text { Knowledge } \\
\text { of Natural } \\
\text { Disasters, } \\
\text { They Could } \\
\text { Happen } \\
\text { Anywhere } \\
\text { Around the } \\
\text { World }\end{array}$ & $\begin{array}{l}\text { The students are } \\
\text { able to: } \\
\text { - Summarize } \\
\text { information } \\
\text { from a text } \\
\text { - Synthesize } \\
\text { information } \\
\text { from a text } \\
\text { - Criticize } \\
\text { author's } \\
\text { opinion in a } \\
\text { text }\end{array}$ & $\begin{array}{l}\text { READING: } \\
\text { Reading the following texts: } \\
\text { - Science } \\
\text { What Is a Natural Disaster? } \\
\text { - Social Studies } \\
\text { Helping Children after Natural } \\
\text { Disasters: Information for Parents } \\
\text { and Teachers } \\
\text { - Literature } \\
\text { Post-Tsunami Storytelling in } \\
\text { Indonesia } \\
\text { - Mathematics } \\
\text { House Damaged in a Natural } \\
\text { Disaster? Claim Your Loss! } \\
\text { - Islamic Studies } \\
\text { Understand Islam: Natural }\end{array}$ & $\begin{array}{l}\text { VOCABULARY } \\
\text { Adjective } \\
\text { Suffixes } \\
\text { GRAMMAR } \\
\text { Conditional } \\
\text { Statements } \\
\text { (If Statements) }\end{array}$ & $187-226$ \\
\hline
\end{tabular}


Disasters or Divine Punishment in

Islam?

\section{LISTENING:}

Listening to the speakers in the

video "Education for Disaster

Preparedness" - "Pray for Indonesia

Wasior Mentawai Merapi Disasters"

partner's response, other students'

comments

\section{SPEAKING:}

Telling, discussing, presenting ideas, asking and answering questions, asking/giving comments, and describing pictures of "Wasior

Mentawai Merapi Disasters"

\section{WRITING:}

Writing answers, main points, conclusions, stories, and reading reports

The results of effectiveness testing of reading materials through experimental design using pretest-posttest control group design were summarized in table 2.

Table 2. The Results of Independence Samples Test

\begin{tabular}{lccc}
\hline \multicolumn{1}{c}{ Reading Materials } & \multicolumn{3}{c}{ Independent Samples T-Test } \\
\hline Whole Language Reading & $\mathrm{T}$ & $\mathrm{Df}$ & Sig. (2-tailed) \\
\cline { 2 - 4 } $\begin{array}{l}\text { materials \& currently used } \\
\text { reading materials }\end{array}$ & -4.051 & 66 & 0.000 \\
\hline
\end{tabular}

As table 1 demonstrates, there was a significant difference on students' reading achievement between those who were taught using Whole Language Reading materials and those who were taught by using the currently used materials. This was indicated by the result of independent t-test, the significance value of .000. This is smaller than .05, therefore, it can be concluded that Whole Language Reading materials were effective in improving students' English reading achievements.

\section{Discussion}

How are the key features of whole language applied in teaching reading in this Whole Language Reading materials. First, it emphasis on the comprehension of the whole passage, at the same time, gives consideration to the study of grammar, vocabulary, and content. Second, students are encouraged to integrate oral and written English in learning activities by discussing and writing frequently about the texts they read. Through these activities, they can improve their language skills. Third, students are encouraged to read different texts in Religion, Literature, Mathematics, Science, Social Studies, etc. as language (English) does not exist in a vacuum, but exists in all aspects of human life. Fourth, teacher makes full use of contexts to cultivate students' language ability by providing more chances for the students to do some contextual comprehension practice by questioning, predicting, discussing, analyzing the text, etc. Fifth, students cannot be assessed by using tests as the only criteria to measure their reading achievement. Teacher should also evaluate students' homework and reading reports. Sixth, students are encouraged to work collaboratively on their tasks and projects. Teacher creates a good learning atmosphere in which students have the opportunity to state their own views, to hear from others, to discuss their ideas, and to hone their argumentative skills. This can form a lively environment of language learning.

Whole Language Reading (WLR) materials have some strengths and limitations. Here are some of the strengths. First, WLR is designed to help students improve their reading comprehension skills and higher order thinking skills needed to achieve a college-level reading proficiency. WLR is also appropriate for helping students develop their knowledge of other disciplines because it integrates content across the subject areas. Second, WLR gives emphasis on the comprehension of the whole passage, and at the same time, gives consideration to the study of grammar, vocabulary, and content. Third, students are encouraged to integrate oral and written English by discussing and writing frequently about the texts they read. Through these activities, they can improve their language skills. Fourth, WLR makes full use of contexts to cultivate students' language ability by providing more chances for the students to do some contextual comprehension practice by questioning, predicting, discussing, analyzing the text, etc. Fifth, students are encouraged to work collaboratively on their tasks and projects. This creates a good learning atmosphere in which students have the opportunity to state their own views, to hear from others, to discuss their ideas, and to hone their argumentative skills. 
This can form a lively environment of language learning. This study also has several limitations. First, not all the findings of need analysis can be accommodated in WLR. For example, not all the topics required by the students can be presented in WLR. Second, in this study, the researcher did not examine the effectiveness of WLR in improving students' ability in other language skills such as listening, speaking, or writing.

\section{Conclusion, Implication, and Suggestions}

\subsection{Conclusion}

The final product of the materials consists of a course book entitled Whole Language Reading (WLR) and a teacher's manual. Whole Language Reading provides rich input of reading strategies, variety of topics, concepts, texts, activities, tasks, and evaluations. Using this book makes reading more holistic and meaningful as it provides integration across language skills and subject areas.
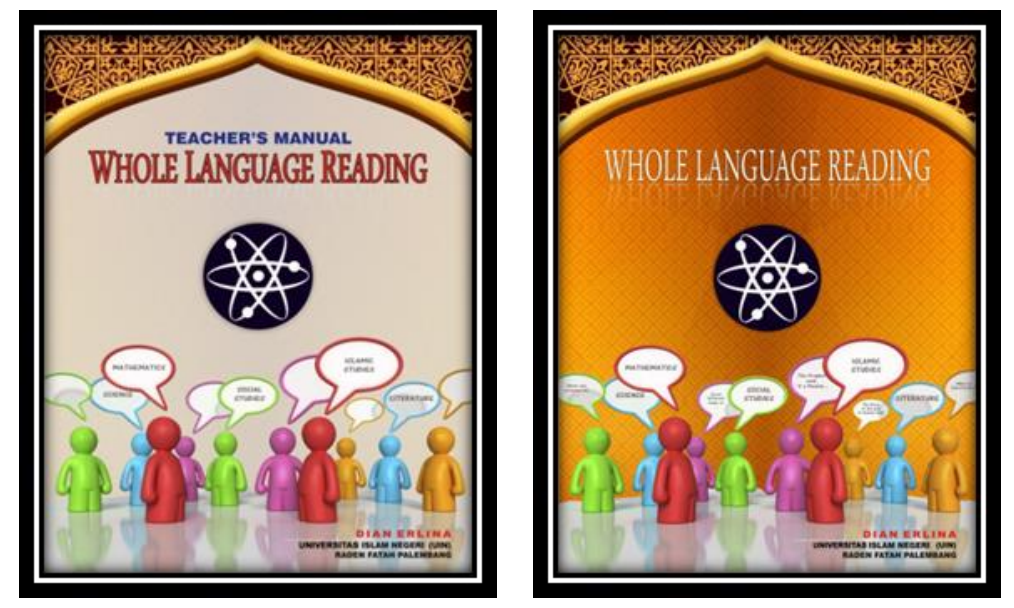

\subsection{Implication}

Whole language-based English reading materials emphasizes the function of language as a tool in all aspects of human life. Therefore, one of the relevant models of reading instruction is integrated reading (reading across subject areas).

\subsection{Suggestions}

Educational institutions need to provide a rich learning environment with a variety of reading sources, print and digital to provide opportunities for students to choose and determine reading materials that suit their needs. WLR developed in this study can be redeveloped using the content of other disciplines. Other researchers can develop other instructional materials based on the principles of whole language. For example, the development of whole language-based English writing materials as whole language concerns about how students learn oral and written language.

\section{References}

Alhaddad, A.S. (2014). Jordanian literacy education: Should whole language be implemented?. European Scientific Journal, 10(8), 409-418.

Bastug, M. (2014). The structural relationship of reading attitude, reading comprehension and academic achievement. International Journal of Social Sciences and Education, 4(4), 931-946.

Borg W. R., \& Meredith D. G. (1983). Educational research: An introduction. New York: Longman Inc.

Bravos, Kalli. (2010). Readability tests and formulas. Retrieved from http://www.ideosity.com/ 2010/01/14/readabilitytests-and-formulas

Brown, H. D. (2007). Teaching by principles: An integrative approach to language pedagogy. New York: Pearson Education, Inc.

Dick, W., Lou, C., \& James, O.C. (2009). The systematic design of instruction. New Jersey: Pearson Education Upper Saddle River.

Eisele, B. (1991). Managing the whole language classroom: A complete teaching resource guide for K-6 teachers. Cypress: Creative Teaching Press, Inc.

Gall, Meredith D., Joyce P. G, \& Walter R. B. (2007). Educational research: An introduction. Boston: Pearson Education, Inc.

Goodman, K. (2005). What's whole in whole language: 20th anniversary edition. Berkeley: RDR Books.

Harwood, Nigel. (2010). English language teaching materials: Theory and practice. Cambridge: Cambridge University Press.

Hedgcock, J. S., \& Dana, R. F. (2009). Teaching readers of English: students, texts, and contexts. New York: Routledge, Taylor \& Francis.

Jolly, D., \& Rod, B. (2011). A framework for materials writing. In Brian Tomlinson (Ed.), Materials development in language teaching. Cambridge: Cambridge University Press. 
McDonough, J., \& Christopher, S. (2005). Materials and methods in ELT: A teacher's guide. Malden: Blackwell Publishing.

Moghadam, J.N. (2011). The importance of whole language approach in teaching English to intermediate Iranian EFL learners. Theory and Practice in Language Studies, 1(11), 1643-1654.

Nation, I.S.P. (2009). Teaching ESL/EFL reading and writing. New York: Routledge, Taylor \& Francis Group.

Qiang, N, Martin, W., \& Teng, H. (2008). China EFL: A new paradigm. Education in China: 21 st century issues and challenges. New York: Nova Science Publishers.

Richards, Jack C. (2005). Curriculum development in language teaching. Cambridge: Cambridge University Press.

Routman, R. (1991). Invitations. Toronto: Irwin Publishing.

Sidek, Horison Mohd. (2012). EFL reading instruction: Communicative task-based approach. International Journal of Instruction, 5(2), 109-110.

Taylor, M. (2007). Whole language teaching is wholehearted activism. In Monica Taylor (Ed.), Whole language teaching, whole-hearted practice: Looking back, looking forward. New York: Peter Lang Publishers, Inc.

Tomlinson, B. \& Hitomi, M. (2010). Published research on materials development for language learning. In Tomlinson, B., \& Masuhara, H. (Eds.), Research for materials development in language learning: Evidence for best practice. New York: Continuum International Publishing Group.

Tomlinson, B. (2007). Materials evaluation. In Tomlinson, B. (Ed.) Developing materials for language teaching. New York: Continuum.

Wang, P. (2011). The effect of computer-assisted whole language instruction on Taiwanese university students' English learning. English Language Teaching, 4(4), 10-20.

Weaver, C. (1990). Understanding whole language from principles to practice. Toronto: Irwin Publishing. 